\title{
Local variations in microhabitat use by Stegastes fuscus (Cuvier, 1830) (Teleostei: Pomacentridae) in a tropical reef of Brazil
}

\section{Paulo Roberto de Medeiros ${ }^{1}$, Ana Luisa Pires Moreira² ${ }^{2}$ and Ana Maria Alves de Medeiros ${ }^{3}$}

1Universidade Federal de Campina Grande. Centro de Formação de Professores. Unidade Acadêmica de Ciências Exatas e da Natureza. Rua Sérgio Moreira de Figueiredo, S/N ${ }^{\circ} \quad$ Cajazeiras-PB. Brazil (CEP 58900-000). Email: medeirospr@gmail.com.

2Instituto de Desenvolvimento Sustentável e Meio Ambiente do Rio Grande do Norte (IDEMA). Núcleo de Unidades de Conservação (NUC/IDEMA). Área de Proteção Ambiental dos Recifes de Corais (APARC). Av. Alm. Alexandrino de Alencar, S/N ${ }^{\circ}$. Tirol. Natal/RN (CEP: 59015-350).

${ }^{3}$ Laboratório de Ecologia. Departamento de Sistemática e Ecologia. Centro de Ciências Exatas e da Natureza. Universidade Federal da Paraíba. João Pessoa-PB. Brazil. (CEP 58050-900).

\begin{abstract}
Due to their widespread abundance and territorial habits, damselfishes play central roles in reefs worldwide, but the extent to which they modify the reef's substrate varies both amongst and within species. The present study evaluated microhabitat preferences and the role of the common damselfish Stegastes fuscus (Cuvier, 1830) (Teleostei: Pomacentridae) as a benthic community modifier in a tropical algal-dominated reef. We employed video survey techniques to assess fish density and microhabitat use and, additionally, the biomass of sessile components were compared inside and immediately outside algal farms of $S$. fuscus. Individuals showed pronounced microhabitat preference, but with prominent local (i.e. small-scale) variations in benthic cover. These local variations are reported for the first time and were due to individuals defending one of two contrasting microhabitats (i.e. turf-dominated or Palythoa caribaeorum-dominated). Further, significant differences in the biomass of sessile organisms were observed within algal farms suggesting that $S$. fuscus plays a keystone role in the benthic community of the reef. The implications of the prominent local variation in microhabitat use are discussed and strongly illustrate the behavioral plasticity of this damselfish.
\end{abstract}

Keywords: Damselfish; Habitat Complexity; Benthic Biomass; Southwestern Atlantic.
Received

November 17, 2016

Accepted

December 22, 2016

Released

December 31, 2016

Open Acess Full Text Article

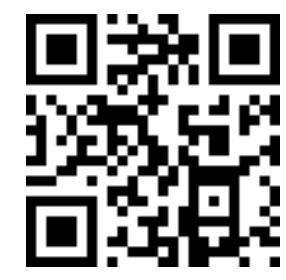

ORCIID

(1) 0000-0002-8534-7331

Paulo Roberto de Medeiros

(1) 0000-0001-7748-6131

Ana Luisa Pires Moreira

(D) 0000-0002-8119-0197

Ana Maria Alves de

Medeiros 


\section{Introduction}

Territorial pomacentrids such as the damselfishes play central roles as benthic modifiers in reefs worldwide (Hixon, 1996; Ceccarelli, 2007). These ecologically significant tasks are largely the result of their ability to specific remove undesired and surplus components, therefore maintaining selected species (Ceccarelli et al., 2001; Ceccarelli et al., 2005) and, often, monoculture algal farms (Hata and Kato, 2002; Hata and Kato 2003). Additionally, effects on the benthic community come about from the territorial exclusion of herbivores (e.g. fishes and sea urchins) via aggressive behaviors (Kamura and Choonhabandit, 1986). Therefore, damselfishes' territories are often regarded as zones of high productivity (Klumpp et al., 1987). Hixon and Brostoff (1983) were amongst the first to demonstrate how damselfishes maintain benthic diversity via intermediate-disturbance, but several other studies also investigated the role of damselfishes as keystone species in reefs worldwide (e.g. Brawley and Adey, 1977; Branch et al., 1992; Ceccarelli et al., 2001; Barneche et al., 2009).

Nonetheless, although territoriality seems to be a behavioral synapomorphy shared by all damselfishes and regarded as somewhat conservative and stereotyped across species, the extent to which damselfishes are able to defend territories is highly variable (Hata and Kato, 2002). For example, the two most common damselfishes in tropical reefs of Brazil (Stegastes fuscus and S. variabilis) show distinct territorial defense patterns, the former being more aggressive towards intruders than the latter (Medeiros et al., 2010a). The extent to which algae are deliberately removed from the territories (i.e. weeding) also differs among species (Ferreira et al., 1998; Ceccarelli et al., 2001; Hata and Kato, 2002). Therefore, variations in algal composition are mostly due to differences in algal biomass and richness within territories of different species (Ceccarelli et al., 2001; Gobler et al., 2006). In fact, variations may also show an intraspecific component, with fish of different size (Foster, 1985) and from different stages (Medeiros et al., 2010a) defending territories with different algal composition.

Hata and Kato (2002; 2004) referred to damselfishes that strongly defend small, monospecific farms and selectively remove unpalatable algae as intensive farmers. On the other hand, territories of less aggressive damselfishes tend to be larger and include indigestible algae, characterizing an extensive farmer. Intensive farmers gain an increased food supply per unit area at the expense of a higher energy prompted during territory defense and weeding, whereas extensive farmers dispend less energy in territory maintenance, but territories are larger due to the low crop yield per unit area.

The overall aim of the present study was to determine microhabitat preference by the dusky damselfish in a tropical shallow reef, and to compare benthic composition inside and outside their territories as a means of understanding the role played by these fishes as benthic community modifiers.

\section{Materials and Methods}

\section{Study area}

The study was conducted at Seixas reefs, João Pessoa, PB, Northeastern, Brazil (Figure 1). It is a shallow ( $<6 \mathrm{~m})$ sandstone reef made up by scattered consolidated substrata surrounded by a contiguous limestone bottom. Common algae include Gelidium spp., Caulerpa racemosa, Halimeda opuntia, Dictyopteris delicatula and Lithothamnium spp. and algal diversity is high throughout the reef. Common sessile animals in the area include the hydrocoral Millepora alcicornis, the zoanthids Palythoa caribaeorum and Protopalythoa variabilis, and the corals Agarices agaricites and Siderastrea stellata. These zoanthids and corals show a somewhat patchy distribution, but with peak abundances in particular microhabitats. 


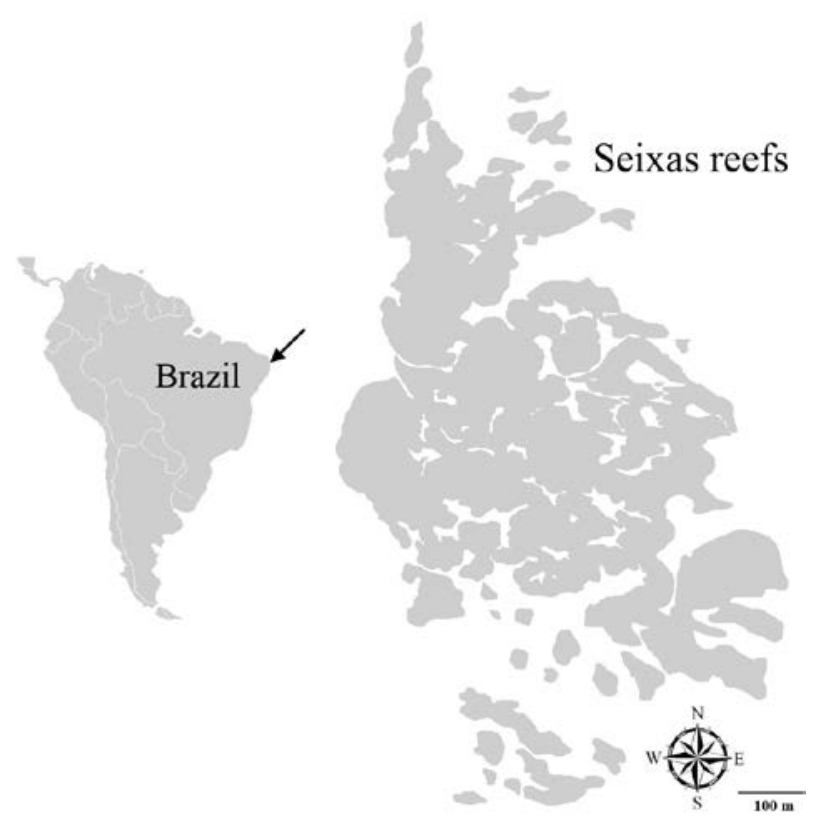

Figure 1. Location and map of the study area.

\section{Microhabitat preferences}

Density of juvenile and adult Stegastes fuscus, and benthic composition were evaluated by means of video surveys on ten randomly assigned $10 \mathrm{~m} \times 2 \mathrm{~m}$ transects (length $\mathrm{x}$ width). Data were recorded during daytime by the same diver in January 2013 at depths below $2 \mathrm{~m}$ and during low tides. Video was recorded using high definition configuration using a Canon digital camera equipped with appropriate water housing. In each transect, one diver swam at constant speed, resulting in transects lasting (mean \pm SD) 2 min $19 \mathrm{sec}$ $\pm 9 \mathrm{sec}$ (average diver speed: $4.32 \mathrm{~m} \cdot \mathrm{min}^{-1}$ ).

To determine the density of S. fuscus, each video was cautiously examined three times and individuals (settled juveniles and adults) were quantified. Repeated counts were conducted as a means of minimizing observer error during video quantification. Nonetheless, divergences among counts within each video transect were not observed whatsoever.

Given that the video transects included all microhabitats of the reef (some of which were not occupied by $S$. fuscus), we evaluated the degree of microhabitat fidelity by comparing benthic composition of still frames where one or more $S$. fuscus individuals appeared in the center frame (total of 33 frames) with 50, randomly chosen frames (with or without $S$. fuscus). This was done to test the degree of randomness in microhabitat use and to specific determine composition of algal farms in relation to the overall benthic composition. Therefore, benthic estimates were treated in a twofold manner: observed (benthic cover estimated in still frames exclusively associated to $S$. fuscus; i.e. the actual microhabitat use) versus randomly expected (benthic cover estimated in all microhabitats, associated or not to $S$. fuscus). Twenty points were randomly plotted on each still frame and assigned to one of ten categories, as follows: fleshy macroalgae (e.g. Dictyopterys, Caulerpa and Sargassum), turf algae (e.g. Gelidium, Griffithsia), Lithothamnium, Halimeda, Protopalythoa variabilis, Palythoa caribaeorum, Zoanthus sociatus, Siderastrea stellata, uncolonized pavement and limestone. Percent cover, therefore, is the relative proportion of a category relative to the overall composition. Number of crevices was also estimated on each still frame. These procedures were conducted on 
Coral Point Count Software (Kohler and Gill, 2006).

Benthic composition and biomass were also evaluated inside and outside the territories of $10 \mathrm{~S}$. fuscus individuals. First, we used focal observations (Lehner, 1996) to determine territory boundaries and, subsequently, benthic samples were collected from inside and outside the territories. Each of 10 focal individuals was observed during 10 minutes, and territory boundaries were marked with natural weights (i.e. rocks). Benthic samples were scraped from a $5 \mathrm{~cm}^{2}$ quadrate inside and immediately outside defended areas and stored in plastic containers. Samples were preserved in $4 \%$ formalin immediately after collection and, in the laboratory, contents were emptied into a Petri dish and identified to the smallest possible taxonomic category. Following identification, contents were dried in a greenhouse and weighted on a digital scale (0.001 g precision).

\section{Data analysis}

Variables were tested for normality (Kolmogorov-Smirnov test) and, when necessary, square root (continuous variables) or arcsine square root (proportions) transformations were conducted (Underwood, 1997).

A one-way MANOVA (Pillai's trace test statistic) was employed to determine whether microhabitat preference (i.e. the observed microhabitat use by $S$. fuscus) was different than randomly expected based on general benthic cover estimates. This was followed by Tukey's HSD post-hoc tests. One way ANOVAs were employed to determine whether benthic diversity (Shannon's index) and number of crevices were different than randomly expected on this microhabitatscale comparison. Furthermore, we employed simple linear regressions to evaluate relationships between fish density and single benthic categories, benthic diversity, and number of crevices.

To compare biomass values from inside and outside the territories, a MANOVA procedure, similar to the one described above, was conducted. To minimize the effects of rare benthic components, this analysis excluded taxonomic units or functional groups with frequency distribution lower than 20\% considering all samples. Finally, a one way ANOVA was used to test inside/outside territories differences regarding total biomass (i.e. pooled data from the above mentioned categories). This was done separately as a means to avoid autocorrelation of the data.

\section{Results}

Mean density ( \pm SE) of Stegastes fuscus in the study area was $0.29 \pm 0.09$ individuals per $\mathrm{m}^{2}$ (settled juveniles $=0.03$ \pm 0.01 ; adults $=0.27 \pm 0.09$ ). Differences between observed and expected benthic cover estimates were detected (Pillai's trace $=0.74 ; \mathrm{F}_{10,31}=8.66 ; \mathrm{P}<0.001$ ), suggesting that microhabitat use was different than randomly expected. Benthic categories which significantly contributed to the variation were fleshy macroalgae and Protopalythoa variabilis, due to lower observed percent cover values, and turf algae and Palythoa caribaeorum, due to higher observed values (Table 1). Also, favored sites of $S$. fuscus showed lower benthic diversity (ANOVA; $F=17.71$, $\mathrm{df}=1 ; \mathrm{p}<0.001)$ and higher number of crevices (ANOVA; $\mathrm{F}=9.87, \mathrm{df}=1 ; \mathrm{p}<$ 0.01 ) than randomly expected (Table 1 ).

Three categories (turf algae, P. caribaeorum and number of crevices) were positively related to fish density and three categories (fleshy macroalgae, P. variabilis and benthic diversity) were negatively correlated (Figure 2). 
Table 1 Mean ( \pm SE) observed values of microhabitat use by $S$. fuscus versus expected values from benthic cover estimates, benthic diversity and number of crevices based on video frame surveys. ns: nonsignificant.

\begin{tabular}{lccc}
\hline Category & Observed & Expected & Post hoc results \\
\hline Fleshy macroalgae & $23.59 \pm 3.74$ & $60.90 \pm 5.14$ & $\mathrm{P}<0.001$ \\
Turf algae & $56.44 \pm 5.12$ & $22.93 \pm 6.46$ & $\mathrm{P}<0.001$ \\
Halimeda & $4.13 \pm 2.23$ & $4.31 \pm 1.10$ & $\mathrm{~ns}$ \\
Lithothamnium & $0.56 \pm 0.43$ & $0.62 \pm 0.19$ & $\mathrm{~ns}$ \\
Protopalythoa variabilis & $1.23 \pm 0.82$ & $5.77 \pm 2.29$ & $\mathrm{P}<0.001$ \\
Zoanthus sociatus & $0.79 \pm 0.29$ & $0.83 \pm 0.43$ & $\mathrm{~ns}$ \\
Palythoa caribaeorum & $10.40 \pm 3.78$ & $0.32 \pm 0.21$ & $\mathrm{P}<0.001$ \\
Siderastrea stellata & $0.52 \pm 0.31$ & $0.43 \pm 0.28$ & $\mathrm{~ns}$ \\
Uncolonized pavement & $0.33 \pm 0.23$ & $0.37 \pm 0.27$ & $\mathrm{~ns}$ \\
Limestone & $1.26 \pm 0.99$ & $3.44 \pm 1.07$ & $\mathrm{~ns}$ \\
Benthic diversity & $0.15 \pm 0.04$ & $0.44 \pm 0.08$ & $\mathrm{P}<0.001$ \\
Number of crevices & $6.75 \pm 1.66$ & $1.56 \pm 0.50$ & $\mathrm{P}<0.01$ \\
\hline
\end{tabular}
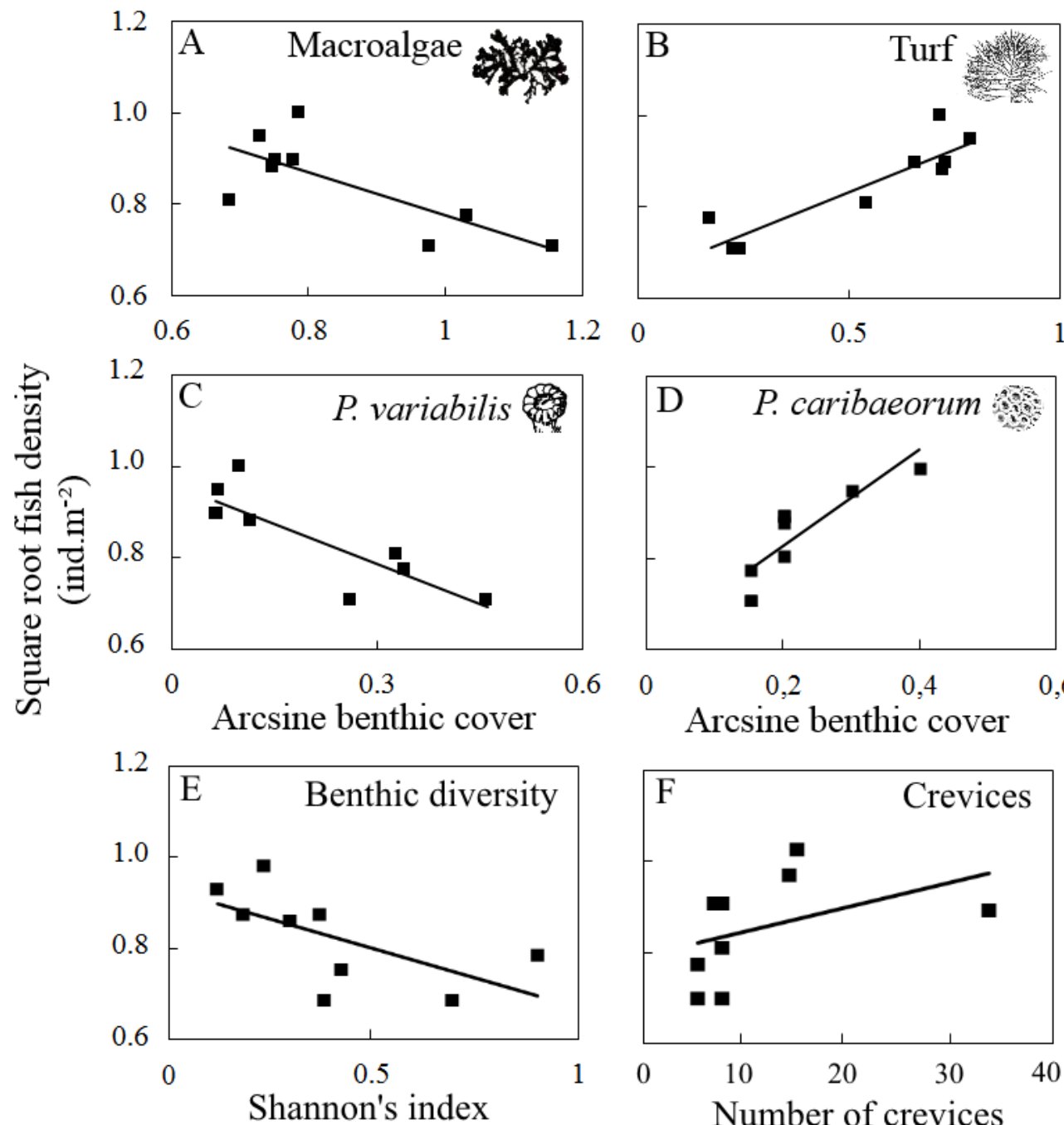

Arcsine benthic cover

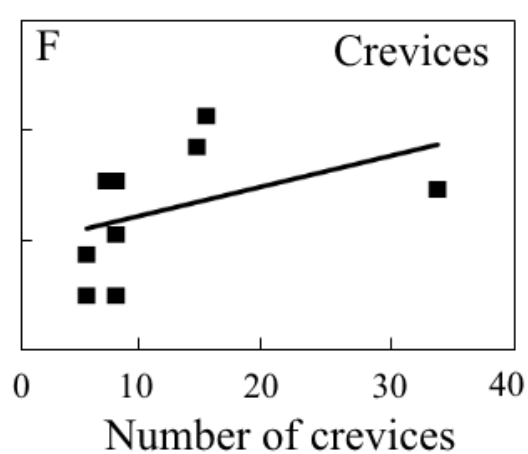

Figure 2. Effect of benthic cover, benthic diversity and number of crevices on the density of S. fuscus. Only significant relationships are shown. a) fleshy macroalgae $\left(\mathrm{r}^{2}=0.55 ; \mathrm{P}<0.05\right)$; b) turf algae $\left(\mathrm{r}^{2}=0.80\right.$; $\left.\mathrm{P}<0.05\right)$; c) Protopalythoa variabilis $\left(\mathrm{r}^{2}=0.72 ; \mathrm{P}<0.05\right)$; d) Palythoa caribaeorum $\left(\mathrm{r}^{2}=0.73\right.$; $\mathrm{P}<0.01)$, e) benthic diversity $\left(\mathrm{r}^{2}=0.79 ; \mathrm{P}<0.01\right)$ and $\left.\mathrm{f}\right)$ number of crevices $\left(\mathrm{r}^{2}=0.69 ; \mathrm{P}<0.01\right)$. 
Video transects revealed six common general microhabitat types: Halimeda-dominated, P. caribaeorumdominated, macroalgae-dominated, P. variabilis-dominated, turf-dominated and limestone-dominated (Figure 3). Based on frequency of observations, $S$. fuscus individuals were very common on turf- and $P$. caribaeorum-dominated microhabitats (>90\% of observations), customary on macroalgae-dominated $(\sim 40 \%)$, rare on Halimeda- and $P$. variabilis-dominated $(<10 \%)$, and not observed whatsoever on limestone-dominated microhabitats (0\%).
Multivariate comparison of taxonomic groups and/or benthic categories biomass revealed differences between the inside and outside of damselfishes territories (Pillai's trace $=0.99 ; \mathrm{F}_{7,2}=30.85$; $\mathrm{P}<0.001$ ). Higher biomass values were observed inside territories for Gelidium sp., Ceramium sp. and $P$. caribaeorum, whereas lower biomass values were observed for Halimeda sp., Lithothamnion sp., Protopalythoa variabilis, sediment and total biomass (Table 2).

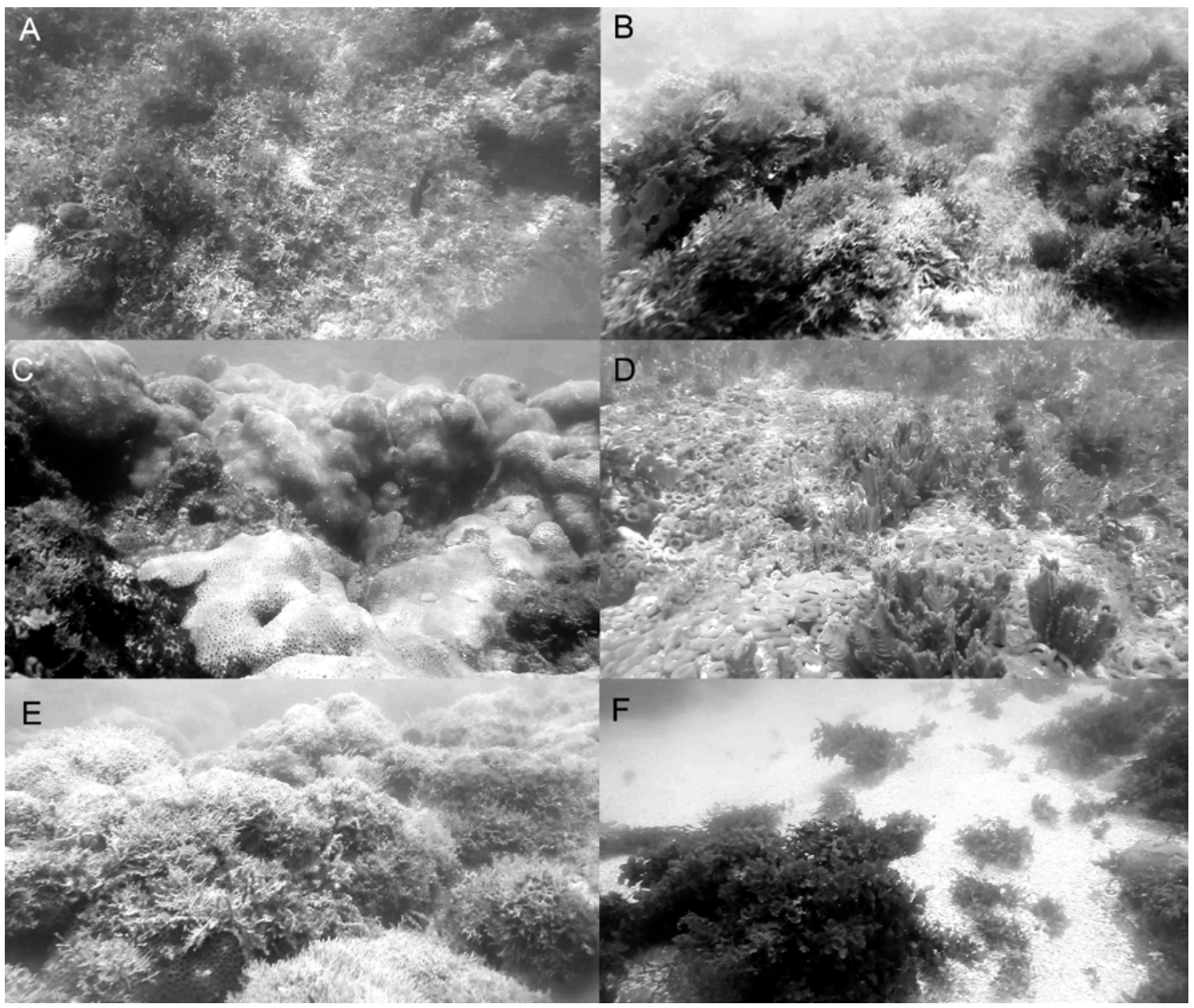

Figure 3. The most common general microhabitat types assessed by means of video surveys in the study area. a) Halimeda-dominated; b) macroalgae-dominated; c) Palythoa caribaeorum-dominated; d) P. variabilis-dominated; e) turf-dominated; and f) limestone-dominated. 
Table 2 Mean $\left( \pm \mathrm{SE}\right.$ ) biomass values $\left(\mathrm{g} / 5 \mathrm{~cm}^{2}\right)$ of taxonomic groups and categories inside and outside territories of Stegastes fuscus. Groups and categories which contributed to less than $30 \%$ of total observations were excluded from the analyses. ns: non-significant.

\begin{tabular}{lcccc}
\hline Taxonomic group & Category & Inside & Outside & Post hoc results \\
\hline Gelidium sp. & Turf algae & $1.43 \pm 0.17$ & $0.01 \pm 0.01$ & $\mathrm{P}<0.001$ \\
Halimeda sp. & Calcareous algae & $1.58 \pm 0.44$ & $3.01 \pm 0.14$ & $\mathrm{P}<0.01$ \\
Dictyopteris sp. & Fleshy macroalgae & $0.05 \pm 0.01$ & $0.07 \pm 0.02$ & $\mathrm{Ns}$ \\
Ceramium sp. & Turf algae & $0.06 \pm 0.01$ & $0.01 \pm 0.01$ & $\mathrm{P}<0.01$ \\
Lithothamnion sp. & Coralline algae & $0.07 \pm 0.04$ & $1.66 \pm 0.42$ & $\mathrm{P}<0.001$ \\
Amphiroa sp. & Calcified macroalgae & $0.06 \pm 0.04$ & $0.01 \pm 0.01$ & $\mathrm{Ns}$ \\
Sargassum sp. & Fleshy macroalgae & $0.01 \pm 0.01$ & $0.03 \pm 0.02$ & $\mathrm{Ns}$ \\
Palythoa caribaeorum & Zoanthid & $0.56 \pm 0.06$ & $0.01 \pm 0.01$ & $\mathrm{P}<0.001$ \\
Protopalythoa variabilis & Zoanthid & $0.01 \pm 0.01$ & $0.35 \pm 0.05$ & $\mathrm{P}<0.001$ \\
\multicolumn{1}{c}{-} & Sediment & $0.16 \pm 0.04$ & $1.94 \pm 0.62$ & $\mathrm{P}<0.001$ \\
\multicolumn{1}{c}{-} & Total biomass & $3.96 \pm 0.33$ & $7.23 \pm 1.10$ & $\mathrm{P}<0.001$ \\
\hline
\end{tabular}

\section{Discussion}

The damselfish Stegastes fuscus is a frequent and abundant component on reefs of Brazil (Ferreira et al., 1998; Osório et al., 2006; Medeiros et al., 2010a), covering up to $90 \%$ of the reef's hard surfaces (Medeiros et al., 2010b). In our study, adults showed a 9-fold higher abundance compared to settled juveniles. Similarly to what has been previously reported for other pomacentrids (Hata and Kato, 2002; Ceccarelli et al., 2001), individuals showed pronounced microhabitat fidelity, but local variations in microhabitat use was observed (i.e. small-scale differences within the study area).

Both microhabitat use and biomass analyses revealed somewhat consistent patterns indicating a strong microhabitat preference. The two general microhabitat types in which $S$. fuscus (both juveniles and adults) was most abundant were dominated by turf algae or Palythoa caribaeorum. Turf-dominated microhabitats were mostly colonized by Gelidium spp. and Ceramium spp., which were positively selected, but other filamentous algae were also abundant (albeit not different from sites immediately outside territories). The unpalatable Dictyopteris (Hay et al., 1988), for example, was tolerated within algal farms. On the other hand, territories located within P. caribaeorum-dominated microhabitats were composed exclusively by this zoanthid.
The two most prominent microhabitats used by $S$. fuscus (turfdominated and P. caribaeorum-dominated) are ecologically distinct and should, therefore, play correspondingly different roles in the ecology of $S$. fuscus. For example, given that turf algae make up a great proportion of $S$. fuscus diet (Ferreira et al., 1998), it is expected that these algae be abundant inside their territories. In contrast, although P. caribaeorum is not reported as an important diet item for S. fuscus (Ferreira et al., 1998; Menegatti et al., 2003; Barneche et al., 2009; Feitosa et al., 2012), extensive areas exclusively colonized by this zoanthid are common in the study area (from several meters to a couple tens of meters long), and S. fuscus density and territory defense remain high even at these sites.

$P$. caribaeorum produces a specific toxin (palytoxin) which is potentially lethal for several species, therefore precluding its utilization by most predators (Moore and Scheuer, 1971; Wiles et al., 1974). Nonetheless, Stegastes species are amongst the few reef fishes which have been reported to feed on $P$. caribaeorum (Francini-Filho and Moura, 2010), and it is possible that their importance in the diet of $S$. fuscus may be underestimated. In fact, although regarded as herbivores, the morphology and histology of the stomach and intestine of $S$. fuscus seem to be adapted for both herbivory and omnivory (see Canan et al., 2012). 
Alternatively, epiphytic microalgae make up a substantial amount of the diet in many pomacentrids (Lassuy, 1984; Ceccarelli et al., 2001) and the extensive P. caribaeorum mats may provide large surface areas for epiphytic microalgae colonization. In fact, Ceccareli et al., (2005) demonstrated that unpalatable algae were maintained within territories of three damselfishes as a means to increase surface area available for epiphytical palatable microalgae growth. Epiphytic associations were not evaluated during our field surveys, but it is possible that territories within P. caribaeorum-dominated microhabitats were defended for epiphytic algal access. Studying the diet of two damselfishes (one of which $S$. fuscus) in a reef of northeastern Brazil with similar geological and biological characteristics as that of the present study, Feitosa et al. (2012) showed that epiphytic diatoms (e.g. Isthmia) were the most abundant item in their diet. Due to their microscopic sizes, microalgae may be obscure in typical diet procedures, and their contribution to the overall diet may be underestimated unless appropriate magnification is employed during stomach content analyses. In addition, microalgae are frequently not assessed in benthic surveys and their availability and importance to reef fish energetic and nutrition may be somewhat neglected (but see John et al., 2001).

Despite their contrasting

differences one common aspect between turf-dominated and P. caribaeorumdominated zones was the high availability of crevices, which is somewhat low at the other microhabitat sites. This highlights the importance of crevices and overall structural complexity on the biology of damselfishes. Crevices and substrate heterogeneity are important as temporary or permanent refuge sites and provide shelter for nests and eggs (e.g. Connell and Jones, 1991; Komyakova et al., 2013). As previously proposed, since turf algae and overall algal abundance are high on northeastern Brazilian reefs, it seems that refuge sites are more limiting than food availability (Medeiros et al., 2010; Medeiros et al., 2014).
Our results suggest that the role of $S$. fuscus as a microhabitat modifier is highly dynamic, with a somewhat high intraspecific territorial plasticity. Benthic diversity showed a nearly 3-fold lower value inside territories, suggesting their potential to modify the substrate.

Calcareous and coralline algae, Protopalythoa variabilis and sediment showed significant lower abundance inside territories, and this seems to be the coupled result of microhabitat selection and deliberate removal of unpalatable components. The hard calcareous skeleton of Halimeda and Lithothamnium, and the presence of unpalatable chemical metabolites render these algae inaccessible and physiologically restricted as a food resource to most fishes (Targett and Targett, 1990). The negative selection towards the zoanthid $P$. variabilis was probably due to the fact that these zoanthids are exclusively found on low complexity zones dominated by fleshy macroalgae which were substantially avoided (i.e. macroalgae-dominated microhabitats; see Figure 3). Sediment makes up a small fraction of the diet of $S$. fuscus (usually less than 2\%) (Feitosa et al., 2012), and is clearly ingested accidentally. The alkaline components of sediments and the hard calcareous skeletons of Halimeda and Lithothamnium, may interfere with the chemical digestion reducing energy assimilation.

Hata and Kato (2004) categorized $S$. fuscus as an extensive farmer based on surveys conducted by Ferreira et al. (1998) at a high latitude tropical rocky shore. Our study suggests, however, that the intensiveextensive categories are opposite ends of a continuum, and that $S$. fuscus lies within these two categories, showing typical characteristics of intensive farmers (i.e. territories with low benthic diversity), but with intermediate-sized territories and tolerance to at least some unpalatable components (see Table 1, in Hata and Kato, 2004).

The present study highlights the role of $S$. fuscus as a keystone benthic modifier in a tropical algal-dominated reef. Furthermore, S. fuscus individuals are 
highly dynamic and defended one of two highly contrasting microhabitats (turf- or P. caribaeorum-dominated). Finally, microhabitats described in the present study are uninterrupted and far from representing discrete components. Nonetheless, they are easily distinguishable in the study area and served as a central functional basis for understanding microhabitat preferences by $S$. fuscus. Future studies comparing diet from individuals defending territories within turf-dominated and P. caribaeorumdominated microhabitats are highly encouraged. Furthermore, our observations suggest that $S$. fuscus individuals are unaffected by the presence of P. caribaeorum and benefit from its aggressive and competitive inhibition against the growth of potential competitors. These relationships are obscure and deserve further attention.

\section{Conflict of interest statement}

Authors declare that they have no conflict of interests.

\section{References}

Barneche, D. R.; Floeter, S. R.; Ceccarelli, D. M.; Frensel, D. M. B.; Dinslaken, D. F.; Mario, H. F. S.; Ferreira, C. E. L. Feeding macroecology of territorial damselfishes (Perciformes: Pomacentridae). Mar. Biol., v. 156, p. 289-299, 2009.

Branch, G. M.; Harris, J. M.; Parkins, C.; Bustamante, R. H.; Eekhout, S. Algal gardening by grazers: a comparison of the ecological effects of territorial fish and limpets. In: John, D. M.; Hawkins, S. J.; Price, J. H. (Eds.). PlantAnimal Interactions in the Marine Benthos. Oxford: Clarendon Press, 1992. p. 405-423.

Brawley, S. H.; Adey, W. H. Territorial behavior of threespot damselfish (Eupomacentrus planifrons) increases reef algal biomass and productivity. Environ. Biol. Fish., v. 2, p. 45-51, 1977.

Canan, B.; Nascimento, W. S.; Silva, N. B.; Chellappa, S. Morphohistology of the digestive tract of the damsel fish Stegastes fuscus (Osteichthyes: Pomacentridae). Scientific World J., v. 2012, Article ID 787316, 9 p., 2012. http://dx.doi.org/10.1100/2012/787316
Ceccarelli, D. M.; Jones, G. P.; McCook, L. J. Territorial damselfishes as determinants of the structure of benthic communities on coral reefs. Oceanogr. Mar. Biol., v. 39, p. 355-389, 2001.

Ceccarelli, D. M.; Jones, G. P.; McCook, L. J. Effects of territorial damselfish on an algaldominated coastal coral reef. Coral Reefs, v. 24, p. 606-620, 2005.

Ceccarelli, D. M. Modification of benthic communities by territorial damselfish: a multispecies comparison. Coral Reefs, v. 26, p. 853866, 2007.

Connell, S. D.; Jones, G. P. The influence of habitat complexity on postrecruitment processes in a temperate reef fish population. J. Exp. Mar. Biol. Ecol., v. 151, no. 2, p. 271-294, $1991 . \quad$ http://dx.doi.org/10.1016/00220981(91)90129-K

Feitosa, J. L.; Concetino, A. M.; Teixeira, S. F.; Ferreira, B. P. Food resource use by two territorial damselfish (Pomacentridae: Stegastes) on South-Western Atlantic algaldominated reefs. J. Sea Res., v. 70, p. 42-49, 2012.

Ferreira, C. E. L.; Gonçalves, J. E. A.; Coutinho, R.; Peret, A. C. Herbivory by the dusky damselfish Stegastes fuscus (Cuvier, 1830) in a tropical rocky shore: effects on the benthic community. J. Exp. Mar. Biol. Ecol., v. 229, p. 241-264, 1998.

Foster, S. A. Size-dependent territory defense by a damselfish: a determinant of resource use by group foraging surgeonfishes. Oecologia, v. 67, p. 499-505, 1985.

Francini-Filho, R. B.; Moura, R. L. Predation on the toxic zoanthid Palythoa caribaeorum by reef fishes in the Abrolhos Bank, Eastern Brazil. Braz. J. Oceanogr., v. 58, p. 77-79, 2010.

Gobler, C. J.; Thibault, D. B.; Davis, T. W.; Curran, P. B.; Peterson, B. J.; Liddle, L. B. Algal assemblages associated with Stegastes sp. territories on Indo-Pacific coral reefs: characterization of diversity and controls on growth. J. Exp. Mar. Biol. Ecol., v. 336, p. 135-145, 2006.

Hata, H.; Kato, M. Weeding by the herbivorous damselfish Stegastes nigricans in nearly monocultural algae farms. Mar. Ecol. Prog. Ser., v. 237, p. 227-231, 2002.

Hata, H.; Kato, M. Demise of monocultural algal farms by exclusion of territorial damselfish. Mar. Ecol. Prog. Ser., v. 263, p. 159-167, 2003.

Hata, H.; Kato, M. Monoculture and mixedspecies algal farms on a coral reef are 
maintained through intensive and extensive management by damselfishes. J. Exp. Mar. Biol. Ecol., v. 313, p. 285-296, 2004.

Hay, M. E.; Duffy, J. E.; Fenical, F.; Gustaison, $K$. Chemical defense in the seaweed Dictyopteris delicatula: differential effects against reef fishes and amphipods. Mar. Ecol. Prog. Ser., v. 48, p. 185-192, 1988.

Hixon, M. A. Effects of reef fishes on corals and algae. In: Birkeland, C. (Ed.). Life and death on coral reefs. New York: Chapman and Hall, 1996. p. 230-248.

Hixon, M. A.; Brostoff, W. N. Damselfish as keystone species in reverse: intermediate disturbance and diversity of reef algae. Science, v. 220, p. 511-513, 1983.

John, M. A. S.; Clemmesen, C.; Lund, T.; Köster, T. Diatom production in the marine environment: implications for larval fish growth and condition. ICES J. Mar. Sci., v. 58, p. 1106-1113, 2001.

Kamura, S.; Choonhabandit, S. Algal communities within territories of the damselfish Stegastes apicalis and the effects of grazing by sea urchins Diadema spp. in the Gulf of Thailand. Galaxea, v. 5, p. 175-193, 1986.

Klumpp, D. W.; McKinnon, A. D.; Daniel, P. Damselfish territories: zones of high productivity on coral reefs. Mar. Ecol. Prog. Ser., v. 40, p. 41-51, 1987.

Kohler, K. E.; Gill, S. M. Coral Point Count with Excel extensions (CPCe): a Visual Basic program for the determination of coral and substrate coverage using random point count methodology. Comput. Geosci., v. 32, p. 12591269, 2006.

Komyakova, V.; Munday, P. L.; Jones, G. P. Relative importance of coral cover, habitat complexity and diversity in determining the structure of reef fish communities. PLoS ONE, v. 8, no. 12, e83178, 2013. http://dx.doi.org/10.1371/journal.pone. 0083178 Lassuy, D. R. Diet, intestinal morphology and nitrogen assimilation efficiency in the damselfish, Stegastes lividus, in Guam. Environ. Biol. Fish., v. 10, p. 183-193, 1984.
Lehner, P. N. Handbook of ethological methods. England: Cambridge University Press, 1996.

Medeiros, P. R.; Souza, A. T.; Ilarri, M. I. Habitat use and behavioural ecology of the juveniles of two sympatric damselfishes (Actinopterygii: Pomacentridae) in the southwestern Atlantic Ocean. J. Fish Biol., v. 77, p. 1599-1615, 2010a.

Medeiros, P. R.; Grempel, R. G.; Souza, A. T.; Ilarri, M. I.; Rosa, R. S. Non-random reef use by fishes at two dominant zones in a tropical, algal-dominated coastal reef. Environ. Biol. Fish., v. 87, p. 237-246, 2010b.

Medeiros, P. R.; Rada, D. P.; Rosa, R. S. Abundance and behavioural ecology of the blenny Ophioblennius trinitatis (Teleostei: Blenniidae) at an oceanic archipelago of Brazil (Atlantic). Sci. Mar., v. 78, p. 203-212, 2014.

Menegatti, J. V.; Vescovi, D. L.; Floeter, S. R. Interações agonísticas e forrageamento do peixe-donzela comum, Stegastes fuscus (Peciformes: Pomacentridae). Nat. Online, v. 1, p. 45-50, 2003.

Moore, R. E.; Scheuer, P. J. Palytoxin: a new marine toxin from a coelenterate. Science, v. 172, p. 495-498, 1971.

Osório, R.; Rosa, I. L.; Cabral, H. Territorial defence by the Brazilian damsel Stegastes fuscus (Teleostei: Pomacentridae). J. Fish Biol., v. 69, p. 233- 242, 2006.

Targett, T. E.; Targett, N. M. Energetics of food selection by the herbivorous parrotfish Sparisoma radians: roles of assimilation efficiency, gut evacuation rate, and algal secondary metabolites. Mar. Ecol. Prog. Ser., v. 66, p. 13-21, 1990.

Underwood, A. J. Experiments in Ecology: their logical design and interpretation using analysis of variance. England: Cambridge University Press, 1997.

Wiles, J. S.; Vick, J. A.; Christensen, M. K. Toxicological evaluation of palytoxin in several animal species. Toxicon, v. 12, p. 427-433, 1974.

License information: This is an open-access article distributed under the terms of the Creative Commons Attribution License, which permits unrestricted use, distribution, and reproduction in any medium, provided the original work is properly cited. 